\title{
STUDI KOMPERATIF ANTARA PENDAPAT IMAM SYAFI'I DAN IMAM MALIKTENTANG PENGAMBILAN BUAH POHON PADA BARANG GADAI TANAH (Studi di Kecamatan Guluk-guluk Kab. Sumenep)
}

\author{
Mondzir \\ Chamim Thohari \\ Universitas Muhammadiyah Surabaya \\ Email : mondzir12@gmail.com
}

\begin{abstract}
This study entitled "a comparative study of Imam Syafi'i and Imam Malik's opinion on Taking Fruit Trees on Land Pawn Goods (Case Study in Guluk-guluk District, Sumenep Regency). The pawning party generally gives the pawn party the land with the fruit of the tree to the pawn recipient and must give the fruit of the tree to the pawn recipient until the pawner pays the debt.

The research method used in this study is the field research method (Case Study) also intended to study intensively about the background of the current situation, as well as the specific social unit environmental interactions that are (given).

The results of this study regarding the taking of fruit trees on earthly pawned goods carried out by the Guluk-guluk District community according to Imam Syafi'i the fruit of the tree is not part of the pawning goods (marhun bih) but the fruit is the property of the mortgaged person (arRaahin ). Meanwhile, according to Imam Malik, the law is permissible if it is used as a pawn condition.
\end{abstract}

Key Words : ar-Rahn, ar-Rahin, al-Murtahin, al-Marhun, al-Marhun bih.

\section{PENDAHULUAAN}

Pembahasan tentang ar-Rahn semakin meluas dan berkembang karena semakin sering dan banyaknya penerapan yang dilakukan oleh ummat dalam akad ar-Rahn. Adapun yang melatar belakangi masyarakat sering melaksanakan gadai adalah karena proses gadai yang tidak membutuhkan waktu yang berlebihan. Selain itu, seseorang dapat menyelesaikan masalah yang dihadapinya dengan menggunakan barang berharga yang dimilikinya sebagai jaminan tanpa harus kehilangan barang tersebut, karena pada akhirnya ketika ia mengembalikan pinjaman yang dia pinjam, maka ia dapat langsung mengambil kembali barang yang dijadikan jaminan tersebut. Sehingga ia dapat memperoleh yang diinginkannya tanpa harus mengorbankan apa yang dimilikinya.

Secara etimologi, ar-Rahn berarti

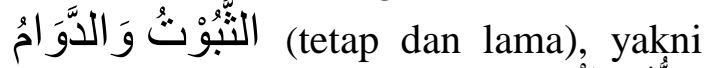

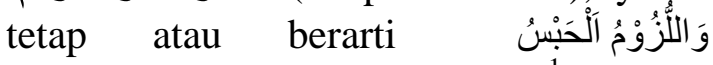
(pengekangan dan keharusan). ${ }^{1}$ Seperti yang tertera dalam QS. Al-Muddatstsir Ayat 38:

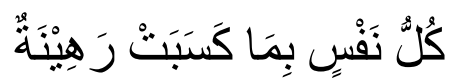

\footnotetext{
${ }^{1}$ Rachmat Syafei, Fiqih Muamalah, (Bandung:
} Pustaka Setia, 2001), 159. 
"Setiap orang bertanggung jawab atas apa yang telah dilakukannya." ${ }^{2}$

Ulama kontemporer Indonesia, Quraish Shihab mengatakan bahwa setiap orang tergadai di sisi Allah SWT. Ia pun harus menebusnya dengan amal-amal perbuatan yang baik. Setiap pribadi tersebut seakan-akan berhutang pada Allah SWT, maka ia harus membayar utang tersebut sebagai cara pembebasan diri atas utang tersebut kepada Allah SWT. ${ }^{3}$

Sedangkan ar-Rahn menurut terminology adalah:

a. Menurut Sayyid Sabiqar-Rahn adalah menjadikan barang berharga menurut pandagan syara' sebagai jaminan utang.

b. Menurut Muhammad Rawwas Qal'ahji bahwa ar-Rahn adalah menguatkan utang dengan jaminan utang. 5

c. Menurut Masjfuk Zuhdi ar-Rahn adalah perjanjian atau akad pinjam meminjam dengan menyerahkan barang sebagai tanggungan hutang. ${ }^{6}$

d. Menurut Nasrun Haroen, ar-Rahn adalah menjadikan suatu barang sebagai jaminan terhadap hak yang mungkin

${ }^{2}$ Departemen Agama RI, Al-Hikmah Al-Quran dan terjemahannya, (Bandung: Diponogoro, 2012), QS. Al-Mudatstsir, ayat: 38, 576.

${ }^{3}$ M. Quraish Shihab, Tafsir al-Misbah, Pesan, Kesan dan Keserasian al- Qur'an, (Jakarta: Lentera Hati, 2006), vol. 14, cet. 4,606

${ }^{4}$ Sayyid Sabiq, Fiqh Sunnah, (Beirut: Dar Kitab Al-Arabi, 1971), jilid 3, 153

5 Muhammad Rawwas Qal'ahji, Ensiklopedi

Fikih Umar bin Khattab R.A (jakarta: Raja Grafindo Persada, 1999), 463

${ }^{6}$ Masjfuk Zuhdi, Masail Fiqhiyah, (Jakarta: CV Hj. Masagung, 1988), cet. 1, 163 dijadikan sebagai pembayaran hak itu, baik keseluruhan ataupun sebagiannya. ${ }^{7}$

Menurut Syaikh Zainuddin ibn Abdil Aziz Al-Malibari mendefisikan ar-Rahn adalah

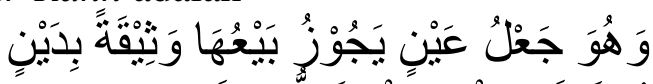

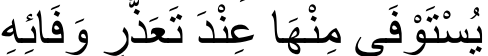

"ar-Rahn adalah menjadikan sesuatu yang boleh diperjualbelikan sebagai jaminan hutang yang diserahkan ketika pelunasan".

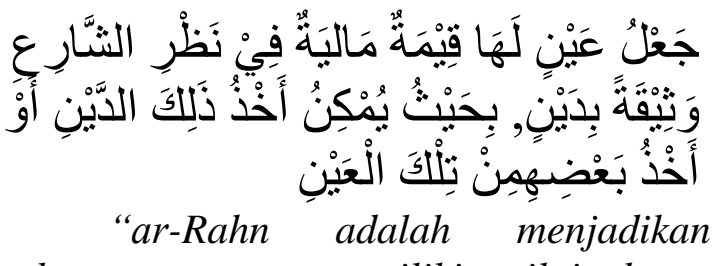
barang yang memiliki nilai harta menurut pandangan syari' yang dijadikan jaminan hutang, dengan ketentuan dimungkinkan untuk mengambil semua utang, atau mengambil sebagiannya dari benda (jaminan) tersebut.",

Ulama Syafi'iyah mendefinisikan ar-Rahn adalah:

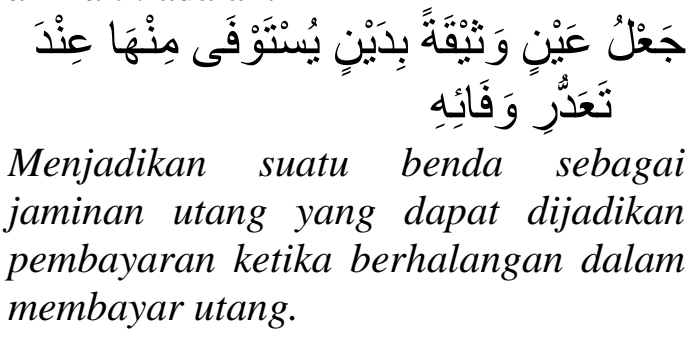

7 Nasrun Haroen, Fiqh Muamalah, (Jakarta: Gaya Media Pratama, 2000), 252

8 Zainuddin ibn Abdil Aziz, Fathul Mu'in, (Surabaya: Nurul Huda),73

9 Sayyid Sabiq, Fiqhus Sunnah,(Beirut: Darul Fikr, 1971),Juz 3, 873 
Berdasarkan pengertian di atas Hasbi as-Shiddieqy mengambil kesimpulan bahwa ar-Rahn adalah:

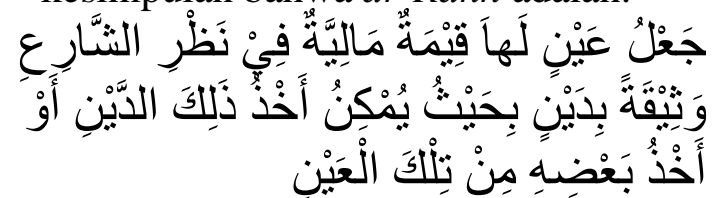

Menjadikan suatu benda berharga dalam pandangan syara' sebagai jaminan atas utang selama ada dua kemungkinan, untuk mengembalikan atau mengambil sebagian benda itu.

Imam Syafi'i menjelaskan bahwa dalam ayat di atas ada kata perintah untuk menulis, baik dalam keadaan muqim maupun dalam keadaan perjalanan dan Allah menamainya sebagai rahn jika mereka dalam keadaan musafir dan tidak menemukan seorang penulis.

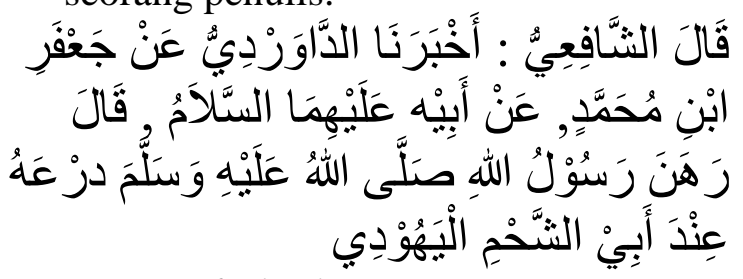

Imam Syaf'i berkata : telah mengabarkan kepada kami ad-Dawardi dari Ja'far ibn Muhammad dari ayahnya Ia berkata Rasulullah telah menggadaikan baju besinya kepada Abu asy-Syahmi dari bangsa Yahudi.

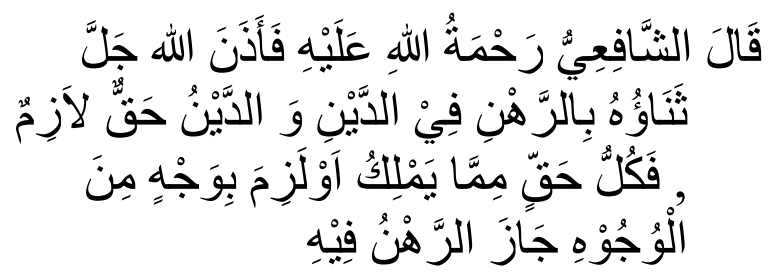

Imam Syafi'i berkata bahwa Allah membolehkan rahn di dalam hutang dan hutang adalah hak yang mengikat maka setiap hak yang dapat dimiliki dengan berbagai cara (jual beli) maka akad rahn hukumnya boleh.

Dalam salah satu kitab karya Imam Malik beliau menjelaskan ketika beliau ditanya "bagaimana pendapat anda tentang orang yang menggadaikan barang dan ia punya hutang yang menghabiskan hartanya dan dan tidak ada yang melunasinya. Apakah boleh rahnnya? Suhun bin Sa'id juga pernah menanyakan pertanyaan yang hampir sma di mana beliau bertanya kepada Imam Malik tentang laki-laki yang melakukan jual beli dengan orang lain sedangkan dia punya hutang apakah dia boleh melakukan akad rahn dan apakah dia tidak dikategorikan orang yang terlarang untuk rahn maka Imam Malik menjawab bahwa rahnnya boleh selama belum termasuk orang yang bangkrut. ${ }^{10}$

Salah satu praktek gadai yang penulis temukan ialah praktek gadai yang dilaksanakan oleh masyarakat GulukGuluk Sumenep. Masyarakat biasanya menggunakan tanah untuk menjadikan marhun (jaminan) dalam melakukan transaksi gadai. Proses gadai tersebut dilakukan dimana rahin dengan menggunakan tanah yang dijadikan marhun, biasanya tanah ini ada yang ada pohon yang berbuah, misalkan pohon mangga, asam, rambutan dan ada yang tidak ada pohonnya. Kemudian rahin akan memperoleh uang sesuai dengan kesepakatan dari murtahin pada akad tersebut, selain itu juga ditentukan waktu berakhirnya akad gadai tersebut. Selama akad gadai tersebut berlangsung, apabila tanah yang ada buahnya tersebut berbuah maka buah tersebut secara otomatis menjadi milik murtahin. Sementara Rahin tidak punya hak untuk mengambil buah pohon dari tanah yang dia gadaikan kepada murtahin, bahkan kalau rahin mau mengambil buah dari pohon itu harus membelinya seperti orang lain

\footnotetext{
10 Imam Malik bin Anas al-Asbahi, alMudawwanah al-Kubro (Beirut: Daar al-Kitab ilmiyyah, 1994) cet. 1,131
} 
karena ia sudah tidak memiliki hak lagi terhadap pohon tersebut sampai dia menebus utangnya.

Sehubungan dengan praktek gadai di Kec. Guluk-Guluk Kab. Sumenep tersebut, penulis tertarik untuk membahasnya mengenai Studi Komperatif antara pendapat Imam Syafi'i dan Imam Malik tentang praktek gadai yang terjadi di Kec. Guluk-Guluk, Kab. Sumenep. Untuk membahas permasalahan tersebut penulis mengambil judul "Studi Komperatif antaraPendapat Imam Syafi dan Imam Malik tentang Pengambilan Buah Pohon pada Barang Gadai Tanah di Kec. Guluk-Guluk, Kab. Sumenep"

\section{METODE PEMBAHASAN}

Dalam penulisan Tesis ini penulis menggunakan jenis penelitian Lapangan (Field Research) yang juga disebut dengan penelitian kasus (Case Study) dimaksudkan untuk mempelajari secara intensif tentang latar belakang keadaan saat ini, serta interaksi lingkungan unit sosial tertentu yang bersifat apa adanya (given). Penelitian kasus ini merupakan studi mendalam mengenai unit sosial tertentu, yang hasil penelitian itu memberi gambaran luas dan mendalam mengenai unit sosial tertentu. ${ }^{11}$ Penelitian ini pada umumnya bertujuan untuk mempelajari secara mendalam terhadap suatu individu, kelompok, institusi, atau masyarakat tertentu, tentang latar belakang, keadaan/ kondisi, faktor-faktor, atau interaksi-interaksi (sosial) yang

11 Sudarwan Danim, Menjadi Peneliti Kualitatif Ancangan metodologi, presentasi dan publikasi hasil penelitian untuk mahasiswa dan peneliti pemula bidang ilmu-ilmu social, pendidikan, dan humaniora, (Bandung: CV. Pustaka Setia, 2002), Cet. I, 54. terjadi di dalamnya. ${ }^{12}$ Dalam hal ini penulis mencoba mengamati langsung mengenai praktek gadai yang dilakukan oleh ar-Rahin dan al-Murtahin yang berada di Kec. Guluk-Guluk, Sumenep. Diharapkan dengan dilakukannya penelitian lapangan ini penulis akan memperoleh data yang akurat mengenai proses dilakukannya akad gadai di Kecamatan Guluk-Guluk tersebut.

\section{PEMBAHASAN}

\section{Konsep ar-Rahn}

\section{Pengertian ar-Rahn}

Secara etimologi, ar-Rahn

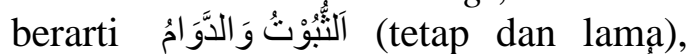

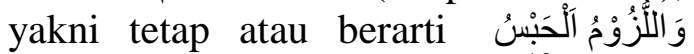
(pengekangan dan keharusan). ${ }^{13}$ Seperti yang tertera dalamQS. Al-Muddatstsir Ayat 38:

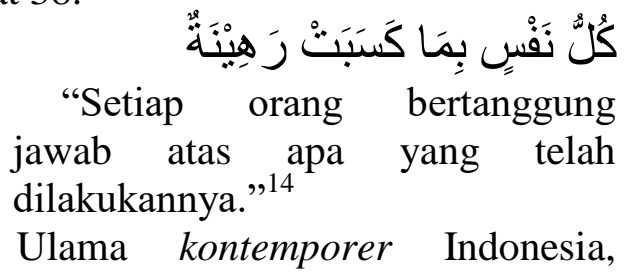
Quraish Shihab mengatakanbahwa setiap orang tergadai di sisi Allah SWT. Ia pun harus menebusnya dengan amal-amal perbuatan yang baik. Setiap pribadi tersebut seakan-akan berhutang pada Allah SWT, maka ia harus membayar utang tersebut sebagai cara pembebasan

12 Bambang Sunggono, Metodologi Penelitian Hukum „Suatu Pengantar, ( Jakarta: PT. Raja Grafindo Persada, 1998), Cet. 2, 36.

${ }^{13}$ Rachmat Syafei, Fiqih Muamalah, (Bandung: Pustaka Setia, 2001), 159.

14 Departemen Agama RI, Al-Hikmah Al-Quran dan terjemahannya, (Bandung: Diponogoro, 2012), QS. Al-Mudatstsir, ayat: 38, 576. 
diri atas utang tersebut kepada Allah SWT. ${ }^{15}$

Sedangkan ar-Rahn menurut terminologi adalah:

Menurut Sayyid Sabiq ar-Rahn adalah menjadikan barang berharga meneurut pandagan syara' sebagai jaminan utang. ${ }^{16}$

Menurut Muhammad Rawwas Qal'ahji bahwa ar-Rahn adalah menguatkan utang dengan jaminan utang. ${ }^{17}$

Menurut Masjfuk Zuhdi ar-Rahn adalah perjanjian atau akad pinjam meminjam dengan menyerahkan barang sebagai tanggungan hutang. ${ }^{18}$

Menurut Nasrun Haroen, ar-Rahn adalah menjadikan suatu barang sebagai jaminan terhadap hak yang mungkin dijadikan sebagai pembayaran hak itu, baik keseluruhan ataupun sebagiannya. ${ }^{19}$

Menurut Syaikh Zainuddin ibn Abdil Aziz Al-Malibari mendefisikan $a r$ Rahn adalah

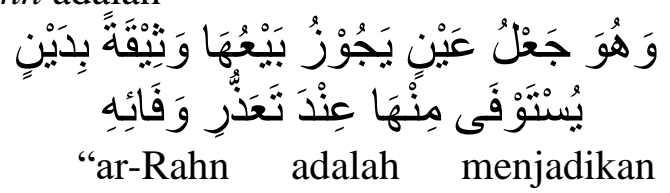

sesuatu yang boleh diperjualbelikan

${ }^{15}$ M. Quraish Shihab, Tafsir al-Misbah, Pesan,

Kesan dan Keserasian al- Qur'an, (Jakarta: Lentera

Hati, 2006), vol. 14, cet. 4,606

${ }^{16}$ Sayyid Sabiq, Fiqh Sunnah, (Beirut: Dar Kitab Al-Arabi, 1971), jilid 3, 153

17 Muhammad Rawwas Qal'ahji, Ensiklopedi

Fikih Umar bin Khattab R.A (jakarta: Raja Grafindo Persada, 1999), 463

${ }^{18}$ Masjfuk Zuhdi, Masail Fiqhiyah, (Jakarta: CV

Hj. Masagung, 1988), cet. 1, 163

19 Nasrun Haroen, Fiqh Muamalah, (Jakarta:

Gaya Media Pratama, 2000), 252 sebagai jaminan hutang yang diserahkan ketika pelunasan". 20

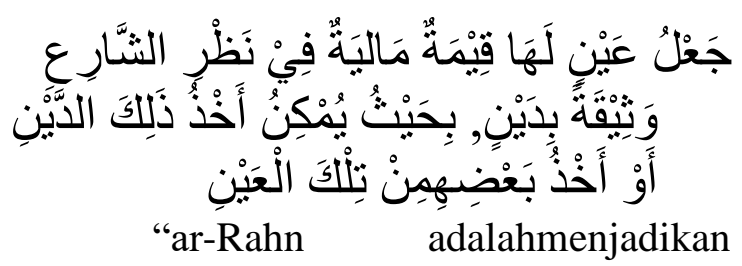

barang yang memiliki nilai harta menurut pandangan syari' yang dijadikan jaminan hutang, dengan ketentuan dimungkinkanuntuk mengambil semua utang, atau mengambil sebagiannya dari benda (jaminan) tersebut." 21

Ulama Syafi'iyah mendefinisikan ar-Rahn adalah:

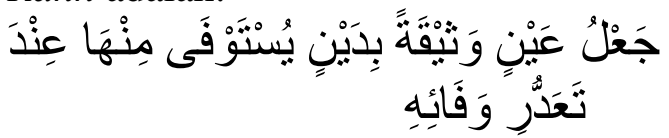

"Menjadikan suatu benda sebagai jaminan utang yang dapat dijadikan pembayaran ketika berhalangan dalam membayar utang."

Berdasarkan pengertian di atas Hasbi as-Shiddieqy mengambil kesimpulan bahwa ar-Rahn adalah:

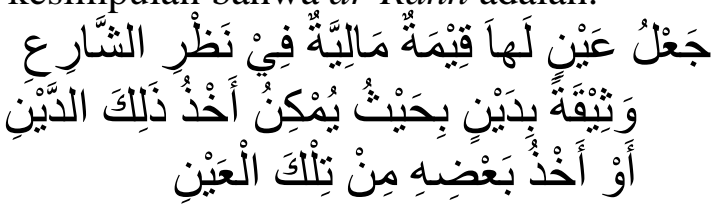

"Menjadikan suatu benda berharga dalam pandangan syara ${ }^{\text {ee }}$ sebagai jaminan atas utang selama ada dua kemungkinan, untuk mengembalikan atau mengambil sebagian benda itu".

Syafi'i Antonio dalam karyanya menjelaskan bahwa Gadai merupakan "suatu akad dimana menahan salah satu

${ }^{20}$ Zainuddin ibn Abdil Aziz, Fathul Mu'in, (Surabaya: Nurul Huda),73

${ }^{21}$ Sayyid Sabiq, Fiqhus Sunnah, Beirut: Darul Fikr, 1971),Juz 3, 873 
harta milik si peminjam sebagai jaminan atas pinjaman yang diterimanya". 22

Pendapat lain disampaikan oleh Al-Imam Abu Zakaria Al-Anshari, menurut beliau bahwasanya ta'rif (definisi) ar-Rahn ialah menjadikan benda yang bersifat harta (harta benda) sebagai kepercayaan dari suatu utang yang dapat dibayarkan dari (harga) benda itu bila utang tidak dibayar. ${ }^{23}$

\section{Hukum ar-Rahn menurut Imam Syafi'i dan Imam Malik}

Para ulama fiqh menyepakati bahwasanya rahn boleh dilakukan dalam perjalanan dan dalam keadaan hadir di tempat, asal barang yang dijaminkan tersebut dapat dipegang/ dikuasai (alqabdh) secara hukum oleh pemberi piutang (murtahin). Dalam hal ini, karena seperti yang kita ketahui bahwasanya tidak semua barang dapat dipegang/ dikuasai secara langsung, dalam keadaan tersebut maka paling tidak ada semacam pegangan yang dapat menjamin bahwa barang dalam status almarhun (menjadi agunan hutang). Misalnya, untuk barang jaminan berupa sebidang tanah maka yang dikuasai surat jaminan atas tanah $(a l$-qabdh $)$ tersebut. $^{24}$

a. Pendapat Imam Syafi'i tentang hukum ar-Rahn

Imam Syafi'i menjelaskan hukum rahn dengan mengutip ayat al-Qur'an yaitu surat alBaqarah, ayat: 282.

${ }^{22}$ Muh. Syafi'i Antonio, Bank Syari'ah Suatu Pengenalan Umum,( Jakarta: Tazkia Institute, 1999), 182.

${ }^{23}$ Chuzaimah T. Yanggo dan A. Hafiz Anshory, A.Z, "Problematika Hukum Islam Kontemporer III", ( Jakarta: Pustaka Firdaus, 2004), Cet. 3, 445

${ }^{24}$ Nasrun Haroen, Fiqh Muamalah, ( Jakarta: Gaya Media Pratama, 2007), Cet. 2, 253

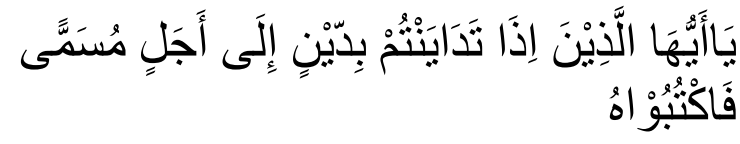

"Wahai orang-orang yang beriman jika kalian bermua'amalah tidak secara tunai pada waktu yang ditentukan maka hendaklah kalian menuliskan itu."

Imam Syafi'i menjelaskan bahwa dalam ayat di atas ada kata perintah untuk menulis, baik dalam keadaan muqim maupun dalam keadaan perjalanan dan Allah menamainya sebagai rahn jika mereka dalam keadaan musafir dan tidak menemukan seorang penulis.

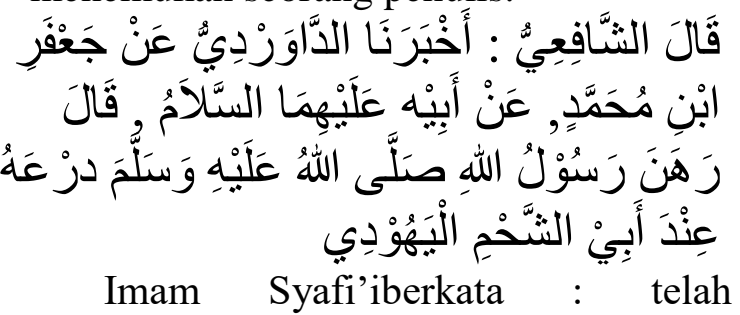
mengabarkan kepada kami ad-Dawardi dari Ja'far ibn Muhammad dari ayahnya Ia berkata "Rasulullah telah menggadaikan baju besinya kepada Abu asy-Syahmi dari bangsa Yahudi

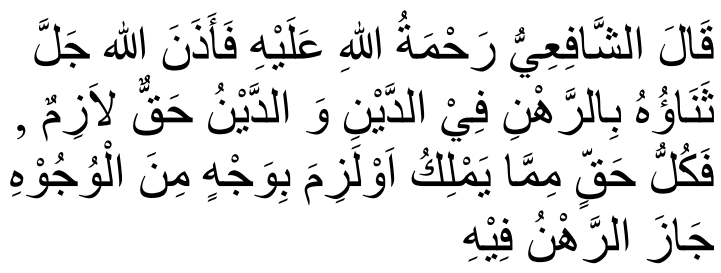

Imam Syafi'i berkata bahwa Allah membolehkan rahn di dalam hutang dan hutang adalah hak yang mengikat maka setiap hak yang dapat dimiliki dengan berbagai cara (jual beli) maka akad rahn hukumnya boleh. ${ }^{25}$

Namun tidak semua rahn itu dibolehkan oleh syafi'i. ada rahn yang menurut Imam Syafi'i tidak boleh sebagaimana yang beliau sampaikan

\footnotetext{
${ }^{25}$ Muhamma bin Idris asy-Syafi' 1 , al-Umm, (
} Maktabah Thibbu: Daarul Wafa, 2001) cet. 1 , 4 ,289 


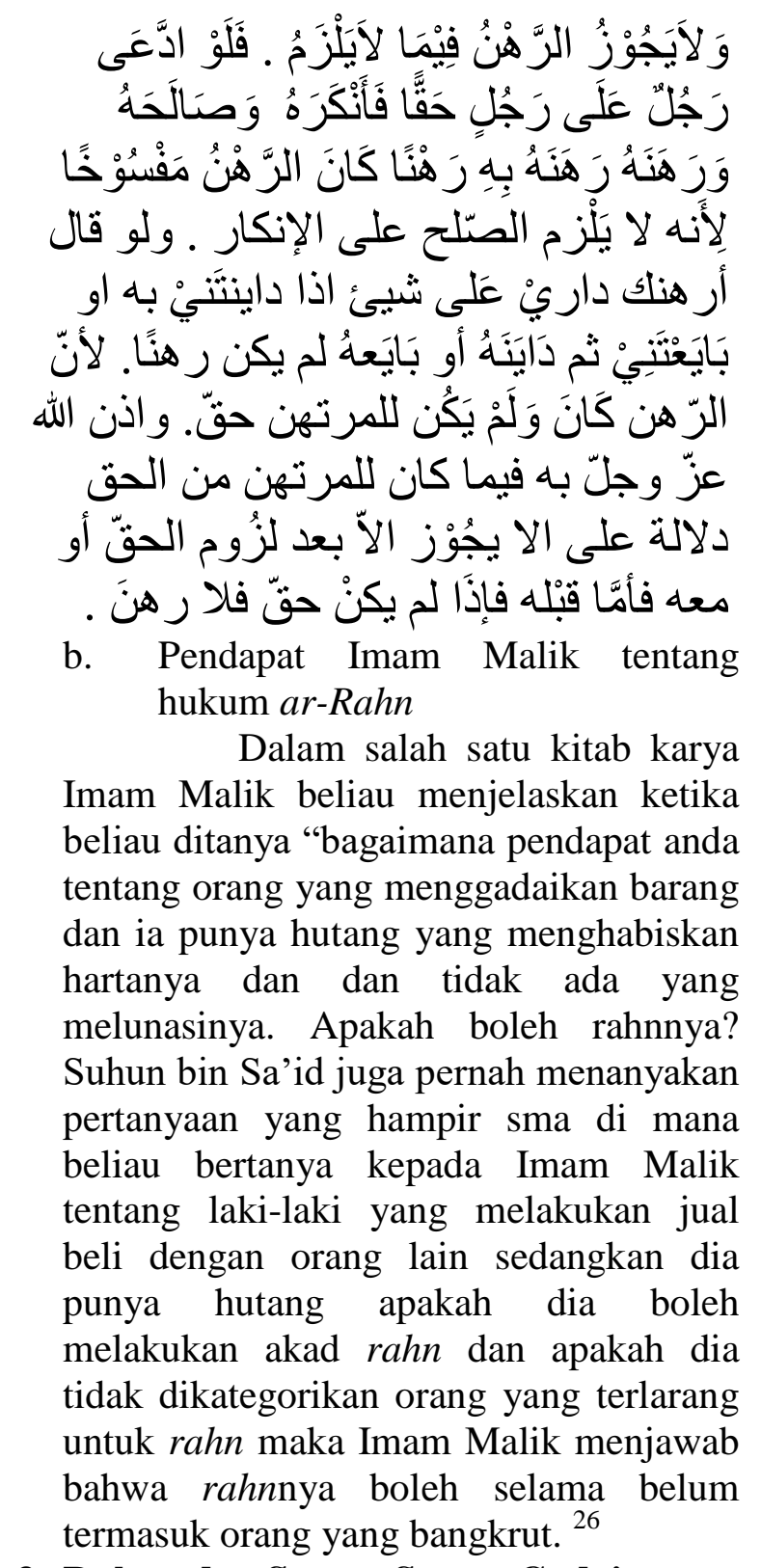

\section{Rukun dan Syarat-Syarat Gadai}

\section{a. Rukun Gadai}

Para ulama fiqih berbeda pendapat dalam menetapkan rukun ar-rahn. Menurut jumhur ulama rukun ar-rahn itu ada empat, yaitu:

1) Sighat atau perkataan.

\footnotetext{
${ }^{26}$ Imam Malik bin Anas al-Asbahi, al-

Mudawwanah al-Kubro (Beirut: Daar al-Kitab

ilmiyyah, 1994) cet. 1, 131
}
2) Adanya pemberi gadai (rahin) dan penerima gadai (murtahin)
3) Adanya barang yang digadaikan (marhun)
4) Adanya utang (murtahin bih) ${ }^{27}$

Adapun ulama Hanafiah berpendapat bahwa rukun ar-rahn hanya ijab dan qabul. Di samping itu, menurut mereka untuk sempurna dan mengikatnya akad rahn ini, maka diperlukan adanya penguasaan barang oleh pemberi utang. Adapun kedua orang yang melakukan akad (ar-rahin dan al-murtahin), harta yang dijadikan jaminan (al-marhun) dan utang (almarhun bih) menurut ulama Hanafiah hanya termasuksyarat-syarat ar-rahn, bukan rukunnya.

1) Sighat atau perkataan

Sighat menurut istilah fuqaha' ialah:

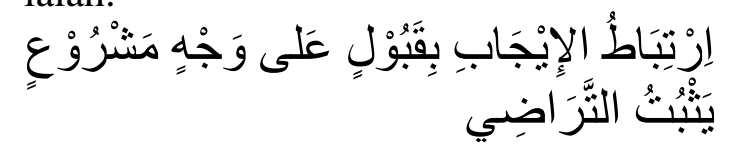

Perkataan antara ijab dan qabul secara yang dibenarkan syara' yang menetapkan keridlaan keduanya (kedua belah pihak) $)^{28}$

2) Adanya pemberi gadai (rahin) dan penerima gadai(murtahin)

Pemberi gadai haruslah orang yang dewasa, berakal, bisa dipercaya, dan memiliki barang yang akan digadaikan. Sedangkan penerima gadai adalah orang, bank, atau lembaga yang dipercaya oleh

27 Choiruman Pasribu Suhrowardi K.Lubis, Hukum Perjanjian dalam Islam, (Jakarta: Sinar Grafika, 1996), cet. 2, 142.

28 TM. Hasbi Ash-Shiddieqi, Pengantar Fiqih Muamalah, (Jakarta: PT. Pustaka Rizki Putra, 1997), Cet.I, 26. 
rahinuntuk mendapatkan modal dengan jaminan barang (gadai). ${ }^{29}$

3) Adanya barang yang digadaikan (marhun)

Barang yang digadaikan harus ada wujud pada saat dilakukan perjanjian gadai dan barang itu adalah barang milik si pemberi gadai (ar-Rahin), barang gadaian itu kemudian berada dibawah pengawasan penerima gadai (al-Murtahin). ${ }^{30}$

4) Adanya hutang (marhun bih)

Hutang (marhum bih) merupakan hak yang wajib diberikan kepada pemiliknya, yang memungkinkan pemanfaatannya (artinya apabila barang tersebut tidak dapat dimanfaatkan, maka tidak sah), dan dapat dihitung jumlahnya. ${ }^{31}$

\section{b. Syarat-syarat Gadai}

Adapun syarat-syarat ar-Rahn para ulama fiqih menyusunnya sesuai dengan rukun ar-Rahn itu sendiri. Dengan demikian syaratsyarat ar-Rahn adalah sebagai berikut:

1) Syarat yang terkait orang berakad (ar-Rahin dan alMurtahin) adalah cakap bertindak hukum. Kecakapan bertindak hukum, menurut jumhur ulama adalah orang yang telah baligh dan berakal. Sedangkan menurut ulama

${ }^{29}$ Heri Sudarsono, Bank dan Lembaga Keuangan Syariah, (Yogyakarta: Ekonisia Kampus Fakultas Ekonomi UII, 2004), 160.

${ }^{30}$ Ahmad Sarwat, Fikih Sehari-hari, (Jakarta: PT. Gramedia Pustaka Utama, 2007), 93.

${ }^{31}$ Heri Sudarsono, Bank dan Lembaga Keuangan

Syariah, 161
Hanafiah kedua belah pihak yang berakad tidak disyaratkan baligh, tetapi cukup disyaratkan berakal saja. Oleh sebab itu, menurut mereka anak kecil yang mumayyiz boleh melakukan akad ar-Rahn asalkan mendapat persetujuan dari walinya.

2) Syarat yang terkait dengan sighat, ulama Hanafiah berpendapatdalam akad itu arRahn tidak boleh dikaitkan oleh syarat tertentu. Karena akad arRahn sama dengan akad jual beli. Apabila akad itu dibarengi dengan syarat tertentu maka syaratnya batal sedang akadnya sah. Misalnya, orang yang berutang mensyaratkan apabila tenggang waktu utang telah habis dan utang belum dibayar, maka jaminan atau ar-Rahn itu diperpanjang satu bulan.

Sementara jumhur ulama mengatakan bahwa apabila syarat itu ialah syarat yang mendukung kelancaran akad itu, maka syarat itu diperbolehkan, tetapi apabila syarat itu bertentangan dengan tabiaat akad ar-Rahn, maka syaratnya batal. Perpanjangan ar-Rahn satu bulan dalam contoh syarat di atas termasuk syarat yang tidak sesuai dengan tabiat arRahn. Karenanya syarat tersebut dinyatakan batal. Syarat yang diperbolehkan itu misalnya, untuk sahnya ar-Rahn, pihak pemberi utang minta agar akad itu disaksikan oleh dua orang saksi.

3) Syarat yang terkait dengan utang (al-Marhun bih) : (a) merupakan hak yang wajib dikembalikan kepada orang yang memberi 
utang, (b) utang itu boleh dilunasi dengan jaminan, dan (c) utang itu jelas dan tertentu.

4) Syarat yang terkait dengan barang yang dijadikan jaminan (al-Marhun), menurut ulama fiqihsyarat-syaratnya sebagai berikut: (a) barang jaminanitu boleh dijual dan nilainya seimbang dengan utang, (b) berharga dan boleh dimanfaatkan, (c) jelas dan tertentu, (d) milik sah orang yang berutang, (e) tidak terkait dengan hak orang lain, (f) merupakan harta utuh dan, (g) boleh diserahkan baik materinya maupun manfaatnya. ${ }^{32}$

5) Disamping syarat-syarat di atas para ulama fiqih sepakat mengatakan, bahwa ar-Rahn itu baru dianggap sempurna apabila barang yang di-rahn-kan itu secara hukum telah berada di tangan pemberi utang, dan uang yang dibutuhkan telah diterima peminjam utang.

Apabila jaminan itu berupa benda berupa benda tidak bergerak seperti rumah dan tanah, maka tidak harus rumah dan tanah yang diberikan, tetapi cukup surat jaminan tanah atau surat-surat tanah itu yang diberikan kepada orang yang memberikan piutang. Syarat yang terakhir demi kesempurnaan ar-Rahn adalah bahwa barang jaminan itu dikuasai secara hukum oleh pemberi piutang. Syarat ini menjadi penting karena Allah

${ }^{32}$ Ibnu Rusyd, Bidayatul al-Muhtaj wa Nihayah al-Muqtashid, (Beirut: Dar al-Fikr, 1978), jilid 2, 268 . dalam Q.S. al-Baqarah : 283 menyatakan barang jaminan itu dipegang atau dikuasai secara hukum oleh pemberi piutang. ${ }^{33}$

\section{Pemanfaatan Barang Gadai oleh rahin dan murtahin}

Adapun pemanfaatan barang gadai ada beberpa pendapat dari para ulama fiqih:

1. Pemanfaatan barang gadai oleh arRahin.

Para ulama berpendapat dengan dua pendapat. jumhur ulama selain Syafi'iyah melarang ar-Rahin untuk memanfaatkan barang gadai atau jaminan, sedangkan ulama Syafi'iyah membolehkannya sejauh tidak memudharatkan al-Murtahin. Secara perinci uraiannya sebagai berikut:

$\begin{array}{rr}\text { a. Ulama } & \text { Syafi'iyah } \\ \text { berpendapat bahwa } & \text { ar-Rahin }\end{array}$ dibolehkan untuk memnfaatkan barang gadai. Jika tidak menyebabkan barang gadai itu berkurang, tidak perlu meminta izin kepada al-Murtahin, seperti mengendarainya, dan menempatinya. Akan tetapi, jika menyebabkan barang gadai tersebut berkurang seperti pengolahan sawah, dan kebun, ar-Rahin harus meminta izin kepada al-Murtahin.

2. Pemanfaatan barang gadai oleh alMurtahin.

Jumhur Ulama selain Hanabilah berpendapat bahwa alMurtahin tidak boleh memanfaatkan barang gadai, kecuali apabila ar-Rahin tidak mau membiayai barang gadai tersebut. Dalam hal ini al-Murtahin dibolehkan mengambil manfaat sekedar untuk mengganti ongkos pembiayaan. Ulama Hanabilah berpendapat bahwa al-Murtahin boleh memanfaatkan

\footnotetext{
${ }^{33}$ Nasrun Haroen, Fiqih Muamalah, 255.
} 
barang gadai, jika berupa kendaraan atau hewan seperti dibolehkan untuk mengendarainya atau mengambil susunya, sekedar pengganti pembiayaan. Lebih jauh pendapat para ulama tentang pemanfaatan barang gadai oleh al-Murtahin sebagai berikut:

Ulama Malikiyah membolehkan alMurtahin memanfaatkan barang gadai, jika diizinkan oleh ar-Rahin atau disyaratkan ketika akad, dan barang gadai terebut merupakan barang yang dapat diperjual belikan serta ditentukan waktunya dengan jelas. Demikian juga pendapat Syafi'iyah.

\section{Tambahan pada Barang Gadai}

Tambahan pada barang gadai yang dimaksudkan dalam hal ini, seperti: buah dari pohon yang digadaikan, hasil bumi, atau upah dan kerja budak. Berkenaan dengan tambahan tersebut, terdapat perbedaan pendapat di antara fuqaha. Sebagian fuqaha berpendapat bahwa tambahan yang terpisah dari barang gadai sama sekali tidak termasuk dalam barang gadai. Sementara sebagian fuqaha yang lainnya berpendapat bahwa seluruh tambahan masuk barang gadai. Berkenaan dengan tambahan pada barang gadai ini, Imam Syafi'i berpendapat:

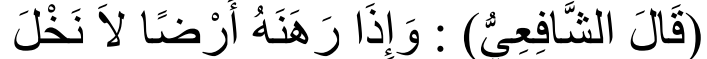

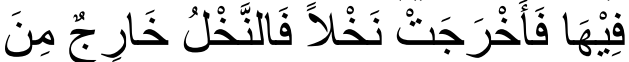

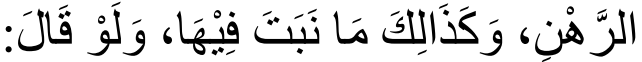

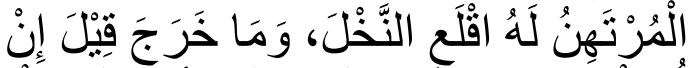

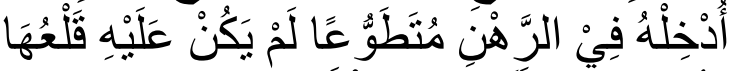

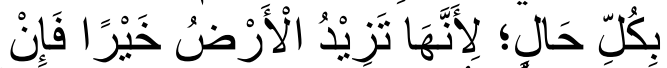

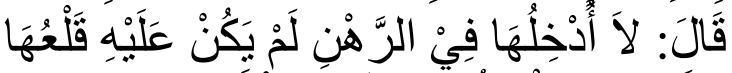

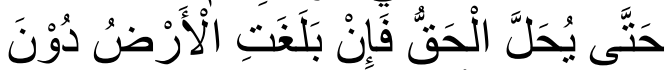

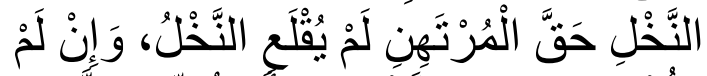

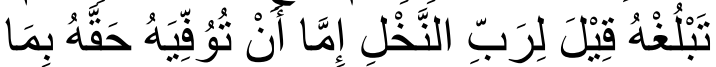

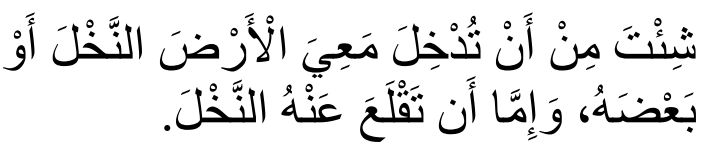

Imam Syafi'i berpendapat: apabila ar-Rahin menggadaikan kepada alMurtahin sebidang tanah yang tidak ada pohon kurmanya kemudian tumbuh pohon kurma maka pohon kurma itu tidak termasuk dalam ar-Rahn dan begitu juga pohon kurma yang sudah tumbuh pada tanah itu dan meskipun al-Murtahin berkata kepada ar-Rahin cabut pohon kurmanya dan pohon yang tumbuhdikatakan "jika saya masukkan dalam ar-Rahn sebagai shodaqah maka tidak boleh dicabut dalam kondisi kayak apapun karena pohon ini menambah kebaikan, tapi jika dikatakan "saya tidak memasukkannya dalam ar-Rahn maka tidak boleh dicabutpohon itu sampai dihalalkan hak itu. ${ }^{34}$

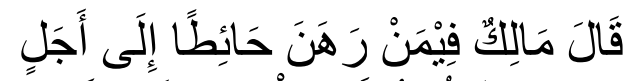

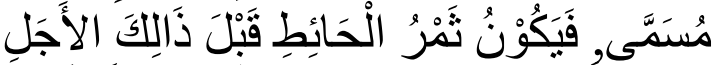

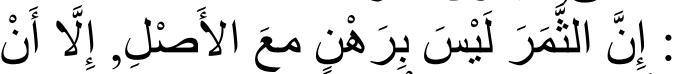

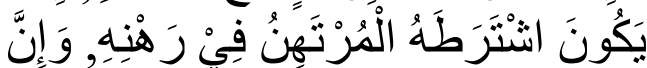

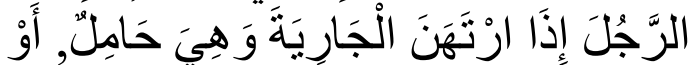

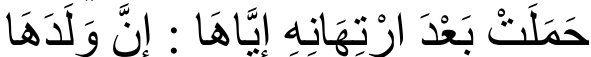

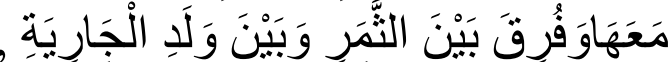

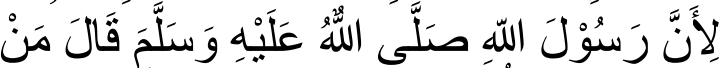

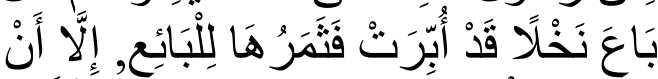

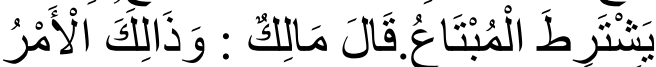

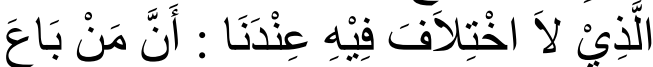

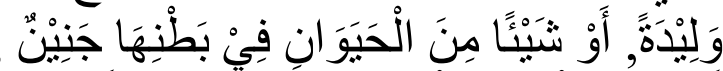

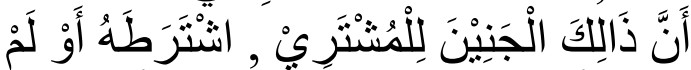

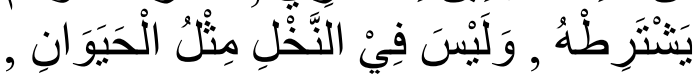

34 Asy-Syafi'ie Abu Abdillah Muhammad ibn Idris, Al-Um, (Riyadh: Dar al-Kutub ath-Thayyibah, 2008), Juz 3, 169. 


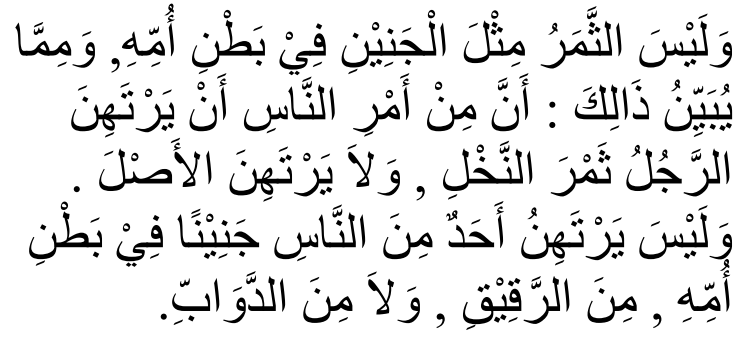

"Imam Malik berkata dalam masalah orang yang menggadaikan sebuah tembok pada jangka waktu yang ditentukan maka kemudian tembok tersebut ada buahnya sebelum jatuh tempo maka sesungguhnya buah-buahan itu adalah bukan termasuk bagian dari gadai bersama asalnya (tembok), kecuali murtahin mensyaratkan buah itu masuk dalam gadaiDan sesungguhnya apabila seseorang menerima gadai hewan ternak sedangkan hewan ternak tersebut dalam keadaan hamil atau hamil setelah terjadinya akad gadai maka sesungguhnya anak dari hewan ternak tersebut masuk dalam rahn. Dan buah sama anaknya hewan ternak memang dibedakan dalam hukunya karena Rasulullah saw bersabda barang siapa yang menjual pohon kurma maka buahnya adalah milik penjual kecuali disyaratkan dalam barang yang dijual. Imam Malik berpendapat bahwa perkara tersebut tidak ada perbedaan karena sesungguhnya orang yang menjual hewan ternak dan di dalam perutnya ada janin maka janin itu kenjadi miliknya pembeli". 35

\section{Perbedaan pendapat antara Imam Syafi'i dan Imam Malik tentang Gadai}

Dalam masalah gadai ada beberapa perbedaan pendapat antara Imam Syafi'i dan Imam Malik yaitu:

35 Malik ibn Anas, Al-Muwattha', ( Beirut: Dar lyath at-Turots al-Arobi, 1985), Juz 2 , 492. a. Imam Syafi'i tidak membolehkan syarat pihak rahin harus menjual rahn kepada murtahin untuk membayar hutangnya saat jatuh tempo. Syarat yang semacam ini tidak dibenarkan oleh Imam Syafi'i dan rahnnya batal. Sedangkan Imam Malik mebolehkan syarat dimana pihak murtahin mensaratkan rahin menjual barang gadaiannya kepada murtahin setelah jatuh tempo

b. Imam Syafi'i juga berpendapat mengenai orang menjadikan rahn dan hutang sekaligus, misalkan pihak murtahin punya uang 10.000.000,-yang kemudian 5.000.000,- untuk digadaikan dan 5.000.000,- untuk dihutangkan maka rahn yang seperti ini menurut Imam Syafi'i tidak dibenarkan. Sedangkkan menurut Imam Malik menjadikan dua akad rahn dan hutang sekaligus itu dibenarkan karena akad rahn itu adalah hutang pada asalnya.

c. Jika terjadi perbedaan pendapat antara rahin dan murtahin dalam masalah hutang pada barang gadai misalkan rahin berkata "saya menggadaikannya 500 dirham" dan murtahin berkata "saya menerima gadai itu 1000 dirham sedangkan harga rahn setara dengan 1000 dirham atau lebih atau di atasnya 500 dirham maka menurut Imam Syafi'i pengakuan yang harus diterima adalah pengakuan pihak rahin. Berbeda dengan pendapat Imam Malik yang berpendapat bahwa pengakuan dan sumpah murtahinlah yang harus diterima

d. Imam Syafi'i tidak membolehkan gadai yang dilakukan secara tidak serah terima barang yang dijadikan gadai karena serah terima barang gadai merupakan salah satu syarat gadai. Sedangkan menurut Imam Malik gadai 
yang dilakukan secara tidak serah terima dibenarkan dan dibolehkan.

7. Persamaan Pendapat antara Imam Syafi'i dan Imam Malik tentang Gadai

Masalah gadai Imam Syafi'i dan Imam Malik ada beberapa persamaan yaitu:

a. Imam Syafi'i dan Imam Malik telah sepakat bahwa hukum gadai itu dibolehkan berdasarkan nash al-Quran dan hadis

b. Menurut Imam Malik dan Imam Syafi'i rahn itu dibolehkan untuk dilaksanakan saat dalam keadaan $\mathrm{p}$ punya hutang

c. Imam Syafi' mengatakan rukun rahn itu ada empat yaitu:

d. Rahin

e. Murtahin

f. Marhun bihi

g. Sighat

Imam Malik juga mengatakan bahwa rukun akad ada empat sebagaimana yang dijelaskan oleh Imam Syafi'i.

\section{KESIMPULAN}

Berdasarkan

permasalahanpermasalahan yang penulis uraikan pada bab sebelumnya maka dapat disimpulkan sebagai berikut:

Praktek pengambilan buah pohon pada barang gadai tanah yang dilakukan oleh masyarakat Kecamatan Guluk-guluk memberikan hak milik buah pohon pada barang gadai tanah kepada al-Murtahin disesuaikan dengan kebiasaan sampai pihak al-Rahin membayar hutangnya kepada al-Murtahin.

Anaisis pendapat Imam Syafi'i dan Imam Malik tehadap pengambilan buah pohon pada barang gadai tanah di Kecamatan Guluk-guluk merupakan praktek pengambilan buah pohon oleh pihak al-Murtahin pada barang gadai tanah menurut Imam Syafi'i buah pohon tersebut merupakan bukan bagian dari barang gadai (marhun bih) akan tetapi buah itu adalah milik orang yang menggadaikan (ar-Raahin) oleh karena barang itu bukan termasuk barang rahn maka murtahin mutlak tidak bisa memanfaatkannya apalagi mengambilnya sebagai hak milik. Akan tetapi, menurut Imam Malik apabila pihak murtahin mensyaratkan buah pohon itu menjadi bagian dari marhun bih maka menurut Imam Malik hukumnya diperbolehkan. Jadi kalau masyarakat kecamatan gulukguluk mensyaratkan buah pohon itu masuk pada barang gadai maka menurut Imam Malik praktek gadai tersebut dapat diterima.

Imam Syafi'i dan Imam Malik sama-sama mengatakan bahwa barang yang tumbuh pada barang gadai bukan bagian dari marhun bih akan tetapi harta yang terpisah. Akan tetapi bedanya kalau Imam Malik mengatakan bisa menjadi bagian dari marhun bih apabila disyaratkan dalam akad rahn. Sedangkan menurut Imam Syafi'i tetap tidak bisa menjadi bagian marhun bih.

\section{DAFTAR PUSTAKA}

Ahmad Idris Marzuki, Jendela Madzhab, Kediri: Lirboyo Press, 2011.

Antonio, Muh. Syafi'i, Bank Syari'ah Suatu Pengenalan Umum, Jakarta: Tazkia Institute, 1999.

Abdurrahman, Muhammad ibn, "Rahmatul Ummah fi Ikhtilaatil Aimmah”, Surabaya: alHidayah. 
Ali, Zainuddin, “Hukum Gadai Syari'ah”, Jakarta: Sinar Grafika, 2008.

Aziz, Zainuddin ibn Abdil, Fathul Mu'in,Surabaya: Nurul Huda.

Anas, Malik ibn, Al-Muwattha',( Muassatur Risalah),Juz 2.

Assiddiqy Hasbi, Pengantar Fiqh Muamalah, Jakarta: Bulan Bintang, 1984.

Antonio, Syafi'i,Bank Syariah dari teori ke praktik, Jakarta: Gema Insani, 2001.

Dewi, Gemala, dkk., "Hukum Perikatan Islam di Indonesia”, Jakarta: Kencana, 2005.

Idris, Asy-Syafi'ie Abu Abdillah Muhammad ibn, Al-Um, Maktabah Syamilah, Juz 3.

Imam Malik bin Anas al-Asbahi, al-Mudawwanah al-Kubro, Beirut: Daar al-Kitab ilmiyyah, 1994.

Haroen, Nasrun, Fiqh Muamalah, Jakarta: Gaya Media Pratama, 2007.

Hadi, Muhamad Sholihul, Pegadaian Syari’ah, Jakarta: Salemba Diniyah, 2003.

Hamidy, Mu'ammal, Terjemah Nailul Authar Jilid IV, Surabaya: BinaIlmu.

K.Lubis, Choiruman Pasribu Suhrowardi, Hukum Perjanjian dalam Islam, (Jakarta: Sinar Grafika, 1996), cet.2.

Nazir, Moh.,Metode Penelitian,Jakarta: Ghalia Indonesia, 1988.

Suryabrata, Sumadi, Metodologi Penelitian, Jakarta: PT. Raja Grafindo Persada, 1995.

Qal'ahji, Muhammad Rawwas, Ensiklopedi Fikih Umar bin Khattab R., A Jakarta: Raja Grafindo Persada, 1999

Rachmat Syafei, Fiqih Muamalah Bandung: Pustaka Setia, 2001.

Rifa'i, Moh.,Terjemah Kifayatul Ahyar, CV. Thoha Putra, Semarang, 1978.

Rusyd, Ibnu, Analisa Fiqih Para Mujtahid, diterjemahkan oleh Imam Ghazali Said dan Achmad Zaidun,Bidayatul Mujtahid wa Nihayatul Muqtashid, Jakarta: Pustaka Amani, Cet. II, 2002.

Sevilla, Consuelo. G., dkk. , Pengantar Metode Penelitian, diterjemahkan oleh Alimuddin Tuwu dari An Introduction to Research Methods,Jakarta: UI-Press, Cet. 1, 1993.

Rasyad Hasan Khalil, Tarih tasyri', Jakarta: Amzah, 2011.

Sabiq Sayyid, Fiqhus Sunnah, Beirut: Daar Al-Fikr, cetakan petama, 1426/ 2006.

Shihab M. Quraish, Tafsir al-Misbah, Pesan, Kesan dan Keserasian al-Qur'an, , Jakarta: Lentera Hati, 2006.

Sudarsono, Heri,Bank dan Lembaga Keuangan syariah, (Yogyakarta: Ekonisia Kampus Fakultas Ekonomi UII, 2004).

Sunggono, Bambang, Metodologi Penelitian Hukum „Suatu Pengantar, Jakarta: PT. Raja Grafindo Persada, 1998.

Sugiyono, Metode Penelitian Kuantitatif Dan Kualitatif Dan R\&D,Bandung: Alfabeta, 2009. Subagyo, Joko, Metode Penelitian Dalam Teori dan Praktek, Jakarta: PT. Rineka Cipta, 1991. Sabiq, Ahmad, kaidah-kaidah praktis memahami fiqih islami, Gresik: Yayasan al-Furqon alIslami, 2013, Zuhdi, Masail Fiqhiyah, Jakarta: CV Hj. Masagung, 1988. 